Vertical Price Control and Parallel Imports

\section{Theory and Evidence}

Keith E. Maskus

Yongmin Chen
Parallel imports are genuine products brought into a country without the authorization of the copyright, patent, or trademark owner. Countries vary considerably in their legal treatment of parallel imports, as determined by their choice of exhaustion doctrine. A new model analyzes parallel imports as a response to vertical pricing arrangements between a rights holder ("manufacturer") and a foreign distributor.

The World Bank

Development Research Group

Trade

October 2000 


\section{Summary findings}

A policy of national exhaustion says that rights to control distribution end upon first sale only within a country, thereby permitting rights holders to exclude parallel imports. A policy of international exhaustion states that such rights end upon first sale anywhere and therefore permits parallel imports. The European Union has a policy of regional exhaustion within its territory. Language in the Agreement on Trade-Related Aspects of Intellectual Property Rights (TRIPS) suggests that this policy choice remains the prerogative of individual countries.

Maskus and Chen review the international policy debate about parallel imports, which are controversial because they erode the ability of intellectual property owners to segment markets. Against considerable opposition, for example, Australia recently deregulated its import controls in major copyrighted goods because domestic prices were evidently sustained at high levels by those controls. Both the European Union and the United States are considering permitting parallel imports of prescription pharmaceuticals from abroad.

Developing countries must consider their exhaustion regimes in the context of competition policies and intellectual property rights.

Economic theory demonstrates that the welfare tradeoffs in regulating parallel imports are complex and depend on circumstances.
Maskus and Chen advance a new model that analyzes parallel imports as a response to vertical pricing arrangements between a rights holder ("manufacturer") and a foreign distributor. In this model, if markets were segmented, the manufacturer would charge a wholesale price to its foreign distributor to ensure an efficient (profit-maximizing) retail price. But if markets were integrated by parallel trade, the distributor could purchase the good at a wholesale price and sell it back to the manufacturer's home market at the local retail price. If transport costs were low enough, this would be profitable, but would diminish the return to the manufacturer and waste resources in costly trade.

So there would be tradeoffs: Parallel imports would benefit consumers in the high-price country but hurt consumers in the low-price country. Such trade forces the manufacturer to set an inefficient wholesale price to limit its extent; it also consumes resources.

The welfare implications of allowing parallel imports are ambiguous. If the costs of engaging in such trade were low, there would be gains from permitting it; if the costs were high, it would be more sensible to ban it. Countries near each other, with low trade barriers, might prefer an open regime of parallel trade.

The vertical pricing model provides an explanation of this pricing behavior that is consistent with manufacturers' preferences to deter parallel trade.

This papcr - a product of Trade, Development Research Group-is part of a larger effort in the group to assess the impact of "second generation" instruments of trade protection on developing countries. Copies of the paper are available free from the World Bank, 1818 H Street NW, Washington, DC 20433. Please contact Lili Tabada, room MC3-333, telephone 202473-6896, fax 202-522-1159, email address ltabada@worldbank.org. Policy Research Working Papers are also posted on the Web at www.worldbank.org/research/workingpapers. The authors may be contacted at keith.maskus@colorado.edu or yongmin.chen@colorado.edu. October 2000.(40 pages)

The Policy Research Working Paper Series disseminates the findings of work in progress to encourage the exchange of ideas about development issues. An objective of the series is to get the findings out quickly, even if the presentations are less than fully polished. The papers carry the names of the authors and should be cited accordingly. The findings, interpretations, and conclusions expressed in this paper are entirely those of the authors. They do not necessarily represent the view of the World Bank, its Executive Directors, or the countries they represent. 


\title{
Vertical Price Control and Parallel Imports: Theory and Evidence
}

\author{
Keith E. Maskus \\ Yongmin Chen \\ Department of Economics, University of Colorado at Boulder \\ Boulder, CO 80309
}

Paper prepared for the joint NBER-ISIT International Trade Seminar June 4-5, 1999. We wish to thank Jonathan Eaton and Damien Neven for insightful comments and Robin Koenigsberg for research assistance.

Maskus: (303)492-7588; fax (303)492-8960; email keith.maskus@colorado.edu

Chen: (303)492-8736; fax (303)492-8960; email yongmin.chen@colorado.edu 



\title{
VERTICAL PRICE CONTROL AND PARALLEL IMPORTS:
}

THEORY AND EVIDENCE.

\author{
Keith E. Maskus
}

Yongmin Chen

Non-technical Summary

Parallel imports are genuine products brought into a country without the authorization of a copyright, patent, or trademark owner. Countries vary considerably in their legal treatment of parallel imports, as determined by their choice of exhaustion doctrine. A policy of national exhaustion says that rights to control distribution end upon first sale only within a country, thereby permitting rights holders to exclude parallel imports. A policy of international exhaustion states that such rights end upon first sale anywhere and therefore permits parallel imports. The European Union has a policy of regional exhaustion within its territory. Language in the TRIPS agreement of the World Trade Organization suggests that this policy choice remains the prerogative of individual countries.

We review the international policy debate about parallel imports, which are controversial because they erode the ability of intellectual property owners to segment markets. For example, over considerable opposition Australia recently deregulated its import controls in major copyrighted goods because domestic prices were evidently sustained at high levels by those controls. Both the European Union and the United States are considering permitting parallel imports of prescription pharmaceuticals from abroad. Developing countries need to consider their exhaustion regimes in the context of competition policies and intellectual property rights.

Economic theory demonstrates that the welfare tradeoffs in regulating parallel imports are complex and dependent on circumstances. We advance a new model that analyzes parallel imports as a response to vertical pricing arrangements between a rights holder ("manufacturer") and a foreign distributor. In this model, if markets 
were segmented the manufacturer would charge a wholesale price to its foreign distributor to ensure an efficient (profit-maximizing) retail price. But if markets were integrated by parallel trade, the distributor could purchase the good at a wholesale price and sell it back to the manufacturer's home market at the local retail price. If transport costs were sufficiently low, this activity would be profitable, though it would diminish the return to the manufacturer and waste resources in costly trade. Therefore, a series of tradeoffs would exist. Parallel imports are beneficial to consumers in the high-price country but detrimental to consumers in the low-price country. Such trade forces the manufacturer to set an inefficient wholesale price in order to limit its extent and also consumes real resources.

Overall, welfare implications of allowing parallel imports are ambiguous. However, we point out that if costs of engaging in such trade are low, there would be gains to permitting it while if such costs are high it would be more sensible to ban it. Thus, while no single policy prescription may be made, it seems that countries with low trade barriers and in close proximity to one another would prefer an open regime of parallel trade.

We perform an econometric test of the model by relating U.S. export prices at the wholesale level across foreign markets to the costs of shipping goods back to the United States. It is found that U.S. import tariffs have the predicted U-shaped impact on export wholesale prices. Thus, the vertical-pricing model provides an explanation for this pricing behavior that is consistent with manufacturer's preferences to deter parallel trade. 


\section{Introduction}

Parallel imports are goods brought into a country without the authorization of the patent, copyright, or trademark owner, after those goods have been placed into circulation legitimately in another market by the rights-owner or her authorized distributor. For example, suppose that an Indonesian authorized dealer of compact disks produced under license to Sony sells them locally at a wholesale price below the retail price prevailing in Australia. If allowed to do so, the dealer or an independent parallel trader could then ship the compact disks to Australia and make a profit net of tariffs and shipping and distribution costs. Because the goods are originally produced and sold under authorization, they are legitimate copies rather than pirated copies or knock-offs. Accordingly, parallel imports are identical to legitimate goods, save for the fact that they may be packaged differently and may not carry the original manufacturer's warranty.

Parallel imports generally are not recorded, so there is uncertainty about how significant they are. As we discuss later, survey evidence suggests that they can capture a consequential share of markets for specific products where such trade is permitted. A prominent example of parallel trade came to light in July, 1999 when concerns arose in Europe about the safety of Coca-Cola products. The Coca-Cola company provides exclusive licenses to bottlers in specific areas of Europe and the licensees are not supposed to sell outside those areas. Nevertheless, international differences in wholesale prices are sufficiently large that parallel trade in bottled soft drinks is common. It is estimated that up to $20 \%$ of the market for Coca-Cola in the United Kingdom is served by parallel imports coming from wholesalers in other European nations. ${ }^{1}$

\footnotetext{
${ }^{1}$ See "Coke's Public-Relations Trouble Was Worsened by Gray Trade," The Wall Street Journal,
} July 6, 1999. 
A country's policy regarding parallel imports stems from its specification of the territorial exhaustion of intellectual property rights (IPRS). Under the doctrine of national exhaustion, rights are exhausted upon first sale within a nation but the ability of IPRS owners to prevent parallel trade between countries remains intact. Under the doctrine of international exhaustion, rights are ended upon first sale anywhere and parallel imports are permitted. An intermediate policy is to adopt regional exhaustion, in which rights are exhausted within a group of countries, thereby permitting parallel trade among them, but are not exhausted outside the region.

The treatment of exhaustion is a core component of a nation's protection for, and regulation of, intellectual property rights. Because IPRS are provided on a territorial or national basis, the global approach to date has been to permit each nation to establish its own policy covering parallel imports. Indeed, despite attempts by the American negotiators in the Uruguay Round to incorporate a global standard of national exhaustion into the Agreement on Trade-Related Aspects of Intellectual Property Rights (TRIPS), no such consensus could be developed. Rather, Article 6 of TRIPS states that:

For the purposes of dispute settlement under this Agreement, subject to the provisions of Articles 3 and 4, nothing in this Agreement shall be used to address the issue of the exhaustion of intellectual property rights.

(Article 3 is a national treatment obligation and Article 4 is a MFN obligation.) Thus, a compromise was reached to preserve the status quo ante on parallel importation. This compromise was important to secure the adherence to TRIPS of numerous developing countries, which reserve the right to set individual policies on exhaustion. However, TRIPS itself is subject to reform in the year 2000 (Maskus, 1998), raising the possibility of this issue being re-visited. Moreover, in laying the groundwork for the new Millenium Round of trade negotiations, U.S. trade authorities have advanced 
the notion of a global rule of national exhaustion, or elimination of parallel trade. Thus, it is an important issue for analysis.

The economic literature on parallel imports is limited. The only formal analysis treats parallel trade as a mechanism for defeating international third-degree price discrimination, with ambiguous welfare impacts (Malueg and Schwartz, 1994). Less formal literature discusses the problems that emerge when parallel traders free ride on the marketing and service investments of authorized distributors (Chard and Mellor, 1989; Barfield and Groombridge, 1998). While these issues are important, the literature has ignored a third point, which is that parallel imports may arise endogenously as a result of efforts by IPRS owners to exert vertical price control in unsegmented markets. In this paper, we shall focus on this point and argue that the issue of parallel imports can, to a certain extent, be viewed and understood as an issue of vertical price control.

The basic logic behind our theory of parallel trade is simple and can be stated as follows. When a manufacturer sells its product through an agent (distributor) in a certain country, the manufacturer has the incentive to charge the agent a wholesale price that is sufficiently low in order to induce a desirable retail price on that market, provided that the manufacturer cannot directly set the retail price. This creates an opportunity for the agent to sell the product profitably in another country, either by the agent himself or through a third party, without the authorization of the manufacturer. We explore this simple logic of parallel trade in a two-country model, and show how in equilibrium the manufacturer balances the tradeoff between achieving efficient vertical pricing and preventing parallel importing. Without legal restriction on parallel importing, the combined social surplus in two countries first decreases and then increases in the private cost of engaging in parallel importing. ${ }^{2}$ Restricting

\footnotetext{
${ }^{2}$ Interestingly, this U-shaped welfare curve is similar to that in Brander and Krugman (1983), although the models and the contexts are very different.
} 
parallel imports always benefits the manufacturer, but it may either raise or reduce the combined social surplus in two countries.

There are several reasons why we believe that it is important to study the problem of parallel imports from the perspective of vertical price control. ${ }^{3}$ First, typically a parallel trader either is an authorized wholesaler himself or obtains the good from an authorized wholesaler. Thus, it is the wholesale price, not the retail price, that determines the profitability of parallel trade. The formation of prices in the vertical relationship could thus be crucial for our understanding of parallel imports. Second, while the explanation of parallel imports based on service free-riding may well be important for some goods, many products are parallel- traded for which this explanation does not seem satisfactory, including footwear, clothing, soft drinks, and construction equipment. Third, our analysis offers new and interesting insights about the policy debate on parallel imports. In particular, we find that there is an important relationship between declining trade costs (say through trade liberalization) and parallel imports, with the latter more likely contributing positively to global surplus as trade costs are reduced.

The prevention of parallel imports is essentially the enforcement of an exclusive territory for a manufacturer or rights holder in the international context. As such, our study of parallel imports is closely related to the literature on vertical restraints. ${ }^{4}$ While our analysis of parallel trade (or exclusive national territories) is rather different from existing models in this literature, it shares some similar intuition with a recent paper by Chen (1999), which shows how oligopoly price discrimination by competing retailers may make it desirable for a manufacturer to impose resale price maintenance.

The paper proceeds as follows. In the next section we discuss the international

\footnotetext{
${ }^{3}$ Our approach, however, does not exclude other possible theories of parallel imports. As we shall discuss later, our model can be easily modified to incorporate price discrimination and/or service free riding.

${ }^{4}$ See, for instance, the survey by Katz (1989).
} 
policy structure concerning parallel imports. In the third section we develop a simple model of vertical price control, with and without parallel trade, to highlight important tradeoffs that emerge. In the fourth section we present basic and indirect empirical evidence on parallel imports, which are not directly measured in general. Econometric analysis of detailed price data for specific U.S. exports to various countries provides support for the vertical-control model. We conclude in the final section.

\section{The International Policy Structure Regarding Parallel Imports}

The TRIPS Agreement represents the first significant movement toward effective harmonization of national legislation, going well beyond liberalization of border measures. As such, it was impossible to reach agreement on a number of difficult issues. The compromise reached in Article 6 of TRIPS reflects a failure to achieve consensus among competing economic interests (Abbott, 1998). Intellectual-property developers in the United States generally preferred a global rule restricting parallel imports. The European Union wished to preserve its internal exhaustion doctrine. Developing countries tended to advocate a global rule of international exhaustion and were joined in this position by certain small, high-income economies including Australia and New Zealand.

Considerable debate has ensued over the wisdom of amending exhaustion in TRIPS in either of two polarized directions. First, some observers advocate a global ban on parallel imports as a natural extension of the rights of intellectual property owners to control international distribution (Barfield and Groombridge, 1998). Second, others argue for a uniform rule of international exhaustion, placing no restrictions on parallel trade, as a means of integrating markets and disciplining abusive price discrimination and collusion that may arise from purely private contractual territorial restraints. This view may be nuanced by recognition of the need for exemptions from parallel imports in certain sectors (Abbott, 1998). 
That policies differ across countries may be seen from Table 1, which lists the basic status of protection for goods bearing trademarks, patents, and copyrights in selected nations. ${ }^{5}$ The European Union follows a policy of exhaustion in all IPR fields within the Community but bars parallel imports coming from outside its territory. The European Court of Justice (ECJ) has steadfastly upheld the right to re-sell legitimately procured goods within the area as a necessary safeguard for completing the internal market. Two important exceptions exist. First, countries are allowed to preclude parallel imports in pharmaceutical goods if it threatens to interfere with pricing regulations. It is noteworthy that the United Kingdom, Germany, and Denmark, where drug prices are least controlled and therefore highest, are open to parallel imports from other EU nations. Second, the ECJ affirmed that first showing of a theatrical movie or television broadcast abroad does not exhaust international distribution rights in light of the need to exploit copyright through repeated showings in this industry. ${ }^{6}$ (See Table 1.)

American policy on parallel imports is mixed. Within the national economy the United States enforces a "first-sale doctrine", by which rights are exhausted when purchased outside the vertical distribution chain. Thus, U.S. firms cannot preclude purchasers from re-selling products anywhere within the United States. This doctrine is seen as an important policing device for exclusive territories, which are permissible subject to a rule-of-reason inquiry. Regarding parallel imports in trademarked products, the United States follows a "common-control exception", affirmed in a recent Supreme Court decision. ${ }^{7}$ The principle allows trademark owners to block parallel imports except when both the foreign and US trademarks are owned by the same entiry or when the foreign and US trademark owners are in a parent-subsidiary relationship

\footnotetext{
${ }^{5}$ This discussion covers the essential structure of protection but there are many exceptions and nuances to each nation's laws.

${ }^{6}$ Coditel SA v Cine-Vog Films, Case 62/79, March 18, 1980.

${ }^{7} \mathrm{~K}$ Mart Corp. v Cartier, 486 US 281(1987).
} 
(Palia and Keown, 1991; NERA, 1999). Moreover, blocking such imports requires demonstrating that they are not identical in quality to original products and may cause consumer confusion. Owners of American patents are protected from parallel imports under an explicit right of importation. Finally, copyrighted goods are barred from parallel importation by the Copyright Act of 1976. Recent attempts by producers of trademarked goods, such as shampoo, to extend this protection by claiming copyright protection for labels have been turned away by the Supreme Court. ${ }^{8}$

Australia generally permits parallel imports in trademarked goods but permits patent owners to restrict them. Australia removed protection for copyrighted compact disks in late 1998, complementing its earlier limited deregulation of book imports. Japan allows parallel imports in trademarked and patented goods unless they are explicitly barred by contract provisions or the original sale of such goods was subject to price regulation abroad. Under its case law, Japan is substantially more open to parallel imports than is the United States (Abbott, 1998)

Although not listed in Table 1, few developing countries have chosen to restrict parallel imports in any field of protection. In some degree this reflects the general absence or limitations of IPRs and competition policies. However, parallel imports are widely seen as a useful policing device against price collusion arising from exclusive territorial restraints and parallel exports as an opportunity for penetrating foreign markets.

\section{A Simple Model of Parallel Imports}

There are two leading theories about parallel imports, the international price discrimination theory and the free-riding theory. ${ }^{9}$ The former does not incorporate the

\footnotetext{
${ }^{8}$ Quality King Distributors v L'anza Research International, 96-470, March 1998.

${ }^{9}$ Another explanation of parallel imports is international price differences due to national price regulations, particularly in the global pharmaceuticals industry (Danzon, 1997).
} 
fact that typically a manufacturer's good is sold to some intermediate agents before reaching final consumers, while the latter does not explain goods being parallel imported for which service externalities do not appear important. It is therefore important to have a theory of parallel imports that takes into account the vertical relationships that often exist in the marketing of a manufacturer's good internationally but does not necessarily rely on the presence of service externalities.

In this section we develop a model of a firm that sells abroad through a distributor (retailer) and attempts to achieve the profit-maximizing retail price through setting its wholesale price and license (franchise) fee. In Subsection 3a we first analyze the model under the assumption that the distributor is able to parallel export the good back to the initial firm's market, and in Subsection $3 \mathrm{~b}$ we then analyze the economic effects that result if such parallel trade is not allowed legally.

\section{3a. Model Structure}

A manufacturer, $M$, sells its product in two countries, $A$ and $B$. In country $A$, $M$ sells directly to the consumers, or sells through a wholly-owned subsidiary whose retail price is set by $M$. In country $B, M$ sells its product through an independent exclusive distributor, $L$. The demand in $A$ is $q=a-p$, and that in $B$ is $q=1-p$. Hence demand is higher (or lower) in $A$ if $a>1$ (or $a<1$ ), and the two countries have the same demand if $a=1$. Manuacturer $M$ has a constant marginal cost of production $c$, which is normalized to zero, and the retailing cost in both countries is normalized to zero as well. ${ }^{10}$ For convenience, assume $a \leq 2$.

Suppose that $M$ can offer $L$ any contract in the form of $(w, T)$, where $w$ is the wholesale price $L$ purchases from $M$ and $T$ is a transfer payment (franchise fee) from $L$ to $M{ }^{11}$ However, $M$ cannot prevent $L$ from selling the product back to $A$, either

\footnotetext{
${ }^{10}$ The model can be easily extended to include positive retailing costs in both countries.

${ }^{11}$ Equivalently, we can think of $L$ being a licensee of $M$ in country $B$. In this case $T$ will then
} 
directly or through intermediaries. That is, either $M$ cannot legally limit $L^{\prime} s$ territory of sales, or it is too costly for $M$ to enforce any such constraint. ${ }^{12}$ Suppose that $L$ incurs an additional constant marginal cost $g \geq 0$ in selling the good back to $A$. For instance, $g$ could be the additional transportation cost or transaction cost. Assume $g \leq \frac{a}{2}$ so that $L^{\prime} s$ cost of selling the product to $A$ is not too high. Assume that if $L$ sells in Country $A$, it will compete with $M$ in a Cournot fashion in $A$.

In suggesting the simple model above, great emphasis has been placed on the model's tractability. Our purpose is to have a model that not only captures the basic tradeoff a manufacturer faces in achieving optimal vertical pricing and preventing parallel importing when it sells through an independent agent, but also is simple enough to allow for explicit solutions that permit interesting comparative-statics analysis. We note that this model can be modified readily to address the two other important explanations of parallel imports. For instance, the possiblity of free-riding by a parallel importer can be incorporated into the model if we assume instead that $M$ also sells in Country $A$ through an independent distributor and the market demand in $A$ is given by $q=a-p+\phi(F)$, where $F$ is the promotional expenditures of the distributor in $A$ and $\phi(\cdot)$ is some known function. On the other hand, if we assume instead that the manufacturer can directly set the retail price in Country $B$ as well as in Country $A$, then the model is reduced to one of international price discrimination. Our setup of the model allows us to focus on the issue of parallel imports from the perspective of vertical price control.

Let the quantities sold in $A$ by $M$ and $L$ be $q_{a m}$ and $q_{a l}$, respectively, and the quantity sold in $B$ by $L$ be $q_{b}$. A subgame-perfect Nash equilibrium is a pair ( $q_{a m}$, $\left.q_{a l}\right)$ that constitute a Nash equilibrium for any $(w, T)$, together with an optimal choice be the license fee and $w$ the royalty payment per unit of output. Contracts with a fixed fee and per-unit royalty are common in international licensing (Contractor, 1981).

${ }^{12}$ However, we assume that $M$ or any agents of $M$ other than $L$ will not sell in $B$. 
of $q_{b}$ by $L$ for any $(w, T)$ and an optimal choice of $(w, T)$ by $M$.

We start our analysis of the model by considering equilibrium in Country $A$, taking as given any $(w, T)$ that is accepted by $L$. The profits of $M$ and $L$ through sales in $A$ are:

$$
\begin{gathered}
\pi_{a m}=q_{a m}\left[a-\left(q_{a m}+q_{a l}\right)-0\right]+(w-0) q_{a l}, \\
\pi_{a l}=q_{a l}\left[a-\left(q_{a m}+q_{a l}\right)-w-g\right] .
\end{gathered}
$$

The first-order conditions, which are also sufficient here, are:

$$
\begin{gathered}
a-2 q_{a m}-q_{a l}=0, \\
a-q_{a m}-2 q_{a l}-w-g=0,
\end{gathered}
$$

provided $a-2 w-2 g \geq 0$, or $\frac{a-2 g}{2} \geq w$.

Therefore, given any $(w, T)$ that is accepted by $L$, there exists a unique Nash equilibrium in $A,\left(q_{a m}(w), q_{a l}(w)\right)$, given by

$$
\begin{aligned}
& q_{a m}(w)=\frac{a+w+g}{3} ; q_{a l}(w)=\frac{a-2 w-2 g}{3}, \text { if } w \leq \frac{a-2 g}{2} \\
& q_{a m}(w)=\frac{a}{2} ; q_{a l}(w)=0, \text { if } \frac{a-2 g}{2}<w
\end{aligned}
$$

The equilibrium price in Country $A$, as a function of $w$, is

$$
p_{a}(w)= \begin{cases}\frac{a+w+g}{3} & \text { if } \quad w \leq \frac{a-2 g}{2} \\ \frac{a}{2} & \text { if } \quad \frac{a-2 g}{2}<w\end{cases}
$$

When $\frac{a-2 g}{2} \geq w$,

$$
\pi_{a m}(w)=\frac{a+w+g}{3}\left[a-\left(\frac{a+w+g}{3}+\frac{a-2 w-2 g}{3}\right)\right]+w \frac{a-2 w-2 g}{3}
$$




$$
\begin{gathered}
=\frac{(a+w+g)^{2}}{9}+w \frac{a-2 w-2 g}{3} \\
\pi_{a l}(w)=\frac{a-2 w-2 g}{3}\left[a-\left(\frac{a+w+g}{3}+\frac{a-2 w-2 g}{3}\right)-w-g\right]=\frac{(a-2 w-2 g)^{2}}{9} .
\end{gathered}
$$

The industry profit generated through sales in Country $A, \pi_{a}(w)$, thus is

$$
\pi_{a}(w)=\frac{(a+w+g)^{2}}{9}+w \frac{a-2 w-2 g}{3}+\frac{(a-2 w-2 g)^{2}}{9} .
$$

When $\frac{a-2 g}{2}<w$, we have

$$
\pi_{a m}(w)=\pi_{a}(w)=\frac{a^{2}}{4}, \pi_{a l}(w)=0
$$

We next consider output and price in Country $B$, again taking as given any $(w, T)$ that is accepted by $L$. Distributor $L$ solves

$$
\max _{q_{\mathbf{b}}}\left\{\left(1-q_{b}-w\right) q_{b}\right\}
$$

The equilibrium (optimal) price and quantity in $B$ thus are:

$$
p_{b}(w)=\frac{1+w}{2} ; q_{b}(w)=\frac{1-w}{2} .
$$

Firm $L^{\prime} s$ profit in $B$, excluding $T$, is $\pi_{b}(w)=\frac{(1-w)^{2}}{4}$.

We now turn to the equilibrium choice of $(w, T)$ by $M$. In equilibrium, $M$ can extract all the surplus from $L$ by setting

$$
T=T(w) \equiv \pi_{a l}(w)+\pi_{b}(w)
$$

Any contract $(w, T(w))$ is accepted by $L$ in equilibrium. The equilibrium choice of $w$ therefore maximizes the joint industry profits in two countries, $\Pi(w)$, and

$$
\Pi(w)= \begin{cases}\frac{(a+w+g)^{2}}{9}+w \frac{a-2 w-2 g}{3}+\frac{(a-2 w-2 g)^{2}}{9}+\frac{(1-w)^{2}}{4}+w \frac{1-w}{2} & \text { if } w \leq \frac{a-2 g}{2} \\ \frac{a^{2}}{4}+\frac{(1-w)^{2}}{4}+w \frac{1-w}{2} & \text { if } \frac{a-2 g}{2}<w \leq 1\end{cases}
$$


That is,

$$
\Pi(w)=\left\{\begin{array}{lll}
\frac{(a+w+g)^{2}}{9}+w \frac{a-2 w-2 g}{3}+\frac{(a-2 w-2 g)^{2}}{9}+\frac{1-w^{2}}{4} & \text { if } \quad w \leq \frac{a-2 g}{2} \\
\frac{a^{2}}{4}+\frac{1-w^{2}}{4} & \text { if } \quad \frac{a-2 g}{2}<w \leq 1
\end{array}\right.
$$

We have:

Proposition 1 The model has a unique subgame perfect Nash equilibrium. The equilibrium value of $w, w^{*}$, is given by

$$
w^{*}= \begin{cases}\frac{2 a+8 g}{13} & \text { if } \quad g \leq \frac{3}{14} a \\ \frac{a-2 g}{2} & \text { if } g>\frac{3}{14} a\end{cases}
$$

the equilibrium price in Country $A$ is

$$
p_{a}^{*} \equiv p_{a}\left(w^{*}\right)=\left\{\begin{array}{lll}
\frac{5 a+7 g}{13} & \text { if } & g \leq \frac{3}{14} a \\
\frac{a}{2} & \text { if } & g>\frac{3}{14} a
\end{array}\right.
$$

and the equilibrium price in Country $B$ is

$$
p_{b}^{*} \equiv p_{b}\left(w^{*}\right)=\left\{\begin{array}{lll}
\frac{1}{2}+\frac{a+4 g}{13} & \text { if } & g \leq \frac{3}{14} a \\
\frac{1}{2}+\frac{a-2 g}{4} & \text { if } & g>\frac{3}{14} a
\end{array}\right.
$$

Proof. For $w \leq \frac{a-2 g}{2}$,

$$
\Pi(w)=\frac{(a+w+g)^{2}}{9}+w \frac{a-2 w-2 g}{3}+\frac{(a-2 w-2 g)^{2}}{9}+\frac{1-w^{2}}{4} .
$$

The maximizing $w$ satisfies:

$$
\frac{2}{9}(a+w+g)+\frac{a-2 w-2 g}{3}-\frac{2}{3} w-\frac{4}{9}(a-2 w-2 g)-\frac{w}{2}=0
$$

from which we obtain 


$$
w^{*}=\frac{2 a+8 g}{13}
$$

and $w^{*}$ indeed maximizes $\Pi(w)$ for $g \leq \frac{3}{14} a$ since in this case

$$
\frac{2 a+8 g}{13}-\frac{a-2 g}{2}=\frac{-9 a+42 g}{26} \leq 0 \text {. }
$$

If $g>\frac{3}{14} a$, then $\frac{2 a+8 g}{13}>\frac{a-2 g}{2}$, and we must have

$$
w^{*}=\frac{a-2 g}{2}
$$

since $\frac{a^{2}}{4}+\frac{1-w^{2}}{4}$ decreases in $w$.

Substituting $w^{*}$ into $p_{a}(w)$ and $p_{b}(w)$, we obtain $p_{a}^{*}$ and $p_{b}^{*}$.

The uniqueness of the equilibrium follows from the uniqueness of $w^{*}, p_{a}^{*}$, and $p_{b}^{*}$.

Since $q_{a l}\left(w^{*}\right)=\frac{3 a-14 g}{13}>0$ if and only if $g<\frac{3}{14} a$, we have

Proposition 2 Parallel importing occurs in country $A$ if and only if $g<\frac{3}{14} a$.

When $g<\frac{3}{14} a$,

$$
p_{a}^{*}-p_{b}^{*}=\frac{5 a+7 g}{13}-\left(\frac{1}{2}+\frac{a+4 g}{13}\right)=\frac{4 a+3 g}{13}-\frac{1}{2},
$$

which is positive if $a>\frac{13}{8}-\frac{3}{4} g$ and negative if $a<\frac{13}{8}-\frac{3}{4} g$. We thus have:

Corollary 1 Assume $g<\frac{3}{14} a$. There is parallel importing from country $B$ to country $A$ in equilibrium; and prices are higher in $A$ than in $B$ if $a>\frac{13}{8}-\frac{3}{4} g$, and they are lower in $A$ than in $B$ if $a<\frac{13}{8}-\frac{3}{4} g$.

Figure 1 shows in the $(a-g)$-space the relations between parameter values, parallel importing $(P I)$, and the price differences in the two countries. For ease of illustration, the value of $a$ on the horizontal axis starts from 1 and the value of $g$ on the vertical 
axis starts from 0 . The area below the line $g=\frac{3}{14} a$ indicates the combinations of $a$ and $g$ under which there will be parallel importing from $B$ to $A$. The line $g=\frac{13-8 a}{6}$ then separates this area into the region where $p_{a}<p_{b}$ and the region where $p_{a}>p_{b}$. (See Figure 1.)

Our result that parallel imports can flow from a high-price country to a low-price country is in contrast to the findings in the existing theories of parallel imports. The key to the unusual result here is the recognition that the cost of acquiring the product to a parallel trader need not be the market price, but could instead be the wholesale price of the manufacturer. To induce the profit-maximizing retail price in the country sold by an independent agent (a distributor or a retailer), the manufacturer desires to set the wholesale price at its marginal cost of production. But such a wholesale price would create an opportunity for the retailer to engage in parallel trading, selling the product profitably in another country, either directly or through intermediaries, without the authorization of the manufacturer. Parallel imports reduce the profits of the manufacturer (or the joint industry profits in two countries), not only because it creates competition in the country receiving parallel imports, but also because it incurs additional transaction (transportation) costs and it prevents the manufacturer from achieving efficient vertical pricing (setting the wholesale price to marginal cost). When the manufacturer is unable effectively to impose territorial constraint, it can still reduce or eliminate parallel imports by raising the wholesale price to the independent agent, but this leads to less profitable retail price in the country where parallel imports originate. In equilibrium, the manufacturer balances the needs to exercise optimal vertical price control and to limit parallel imports.

When $g<\frac{3}{14} a$,

$$
\Pi\left(w^{*}\right)=\frac{\left(a+\frac{2 a+8 g}{13}+g\right)^{2}}{9}+\frac{2 a+8 g}{13} \frac{a-2 \frac{2 a+8 g}{13}-2 g}{3}+\frac{\left(a-2 \frac{2 a+8 g}{13}-2 g\right)^{2}}{9}+
$$




$$
\frac{1-\left(\frac{2 a+8 g}{13}\right)^{2}}{4}=\frac{3}{13} a^{2}-\frac{2}{13} a g+\frac{9}{13} g^{2}+\frac{1}{4} \text {. }
$$

When $g \geq \frac{3}{14} a$

$$
\Pi\left(w^{*}\right)=\frac{a^{2}}{4}+\frac{1-\left(\frac{a-2 g}{2}\right)^{2}}{4}=\frac{3}{16} a^{2}+\frac{1}{4}+\frac{1}{4} a g-\frac{1}{4} g^{2} .
$$

Therefore, the equilibrium combined industry profit in two countries, which is the same as the profit of the manufacturer in our model, is

$$
\Pi^{*}=\left\{\begin{array}{ccc}
\frac{3}{13} a^{2}-\frac{2}{13} a g+\frac{9}{13} g^{2}+\frac{1}{4} & \text { if } & g \leq \frac{3}{14} a \\
\frac{3}{16} a^{2}+\frac{1}{4}+\frac{1}{4} a g-\frac{1}{4} g^{2} & \text { if } & \frac{3}{14} a<g
\end{array},\right.
$$

which is $\frac{3}{13} a^{2}+\frac{1}{4}$ when $g=0$ and $\frac{1}{4}\left(a^{2}+1\right)>\frac{3}{13} a^{2}+\frac{1}{4}$ when $g=\frac{a}{2}$.

Since

$$
\frac{\partial\left(\frac{3}{13} a^{2}-\frac{2}{13} a g+\frac{9}{13} g^{2}+\frac{1}{4}\right)}{\partial g}=-\frac{2}{13} a+\frac{18}{13} g,
$$

which is negative if $g<\frac{1}{9} a$ and is positive if $g>\frac{1}{9} a$; and since

$$
\frac{\partial\left(\frac{3}{16} a^{2}+\frac{1}{4}+\frac{1}{4} a g-\frac{1}{4} g^{2}\right)}{\partial g}=\frac{1}{4} a-\frac{2 g}{4}>\frac{1}{4} a-\frac{2\left(\frac{a}{2}\right)}{4}=0
$$

we have

Corollary 2 The combined industry profit in two countries decreases in $g$ when $g<$ $\frac{1}{9} a$, increases in $g$ when $g>\frac{1}{9} a$, and it is highest when $g=\frac{a}{2}$.

It is interesting that industry profits are not monotonic in $g$. An increase in $g$ reduces competition in $A$ for any given $w$, but increases the cost of the output sold back to $A$ by $L$.

When $g<\frac{3}{14} a$, the combined consumer surplus in two countries is

$$
\frac{1}{2}\left(a-\frac{5 a+7 g}{13}\right)^{2}+\frac{1}{2}\left(\frac{1}{2}-\frac{a+4 g}{13}\right)^{2} .
$$

When $g>\frac{3}{14} a$, the combined consumer surplus in two countries is: 


$$
\frac{1}{2}\left(\frac{a}{2}\right)^{2}+\frac{1}{2}\left(\frac{1}{2}-\frac{a-2 g}{4}\right)^{2}
$$

Therefore, combined social surplus in two countries, which we shall also call global welfare, or simply welfare when there is no confusion, is

$$
S^{*}=\left\{\begin{array}{lll}
\frac{3}{13} a^{2}-\frac{2}{13} a g+\frac{9}{13} g^{2}+\frac{1}{4}+\frac{1}{2}\left(a-\frac{5 a+7 g}{13}\right)^{2}+\frac{1}{2}\left(\frac{1}{2}-\frac{a+4 g}{13}\right)^{2} & \text { if } \quad g \leq \frac{3}{14} a \\
\frac{3}{16} a^{2}+\frac{1}{4}+\frac{1}{4} a g-\frac{1}{4} g^{2}+\frac{1}{2}\left(\frac{a}{2}\right)^{2}+\frac{1}{2}\left(\frac{1}{2}-\frac{a-2 g}{4}\right)^{2} & \text { if } \quad \frac{3}{14} a<g
\end{array} .\right.
$$

That is

$$
S^{*}=\left\{\begin{array}{lll}
\frac{11}{26} a^{2}-\frac{6}{13} a g+\frac{23}{26} g^{2}+\frac{3}{8}-\frac{1}{26} a-\frac{2}{13} g & \text { if } & g \leq \frac{3}{14} a \\
\frac{11}{32} a^{2}+\frac{3}{8}+\frac{1}{8} a g-\frac{1}{8} g^{2}-\frac{1}{8} a+\frac{1}{4} g & \text { if } & \frac{3}{14} a<g
\end{array} .\right.
$$

Since

$$
\frac{\partial\left(\frac{11}{26} a^{2}-\frac{6}{13} a g+\frac{23}{26} g^{2}+\frac{3}{8}-\frac{1}{26} a-\frac{2}{13} g\right)}{\partial g}=-\frac{6}{13} a+\frac{23}{13} g-\frac{2}{13}<0
$$

for all $g \leq \frac{3}{14} a$, and

$$
\frac{\partial\left(\frac{11}{32} a^{2}+\frac{3}{8}+\frac{1}{8} a g-\frac{1}{8} g^{2}-\frac{1}{8} a+\frac{1}{4} g\right)}{\partial g}=\frac{1}{8} a-\frac{1}{4} g+\frac{1}{4} \geq \frac{1}{8} a-\frac{1}{4}\left(\frac{a}{2}\right)+\frac{1}{4}>0
$$

for all $g \in\left(\frac{3}{14} a, \frac{a}{2}\right]$, we have:

Corollary 3 Combined social surplus $S^{*}$ decreases in $g$ if $g \leq \frac{3}{14} a$, and increases in $g$ if $g>\frac{3}{14} a$.

Thus, there is a $U$-shaped welfare curve with respect to the cost of engaging in parallel importing. This finding connects nicely to the result in Brander and Krugman (1983). They present a model of reciprocal dumping of homogenous goods with symmetric duopolists. However, they do not consider vertical relationships in distribution. They find a similar $U$-shaped welfare curve stemming from a tradeoff 
between resource waste in cross-hauling and procompetitive pricing. It is interesting that welfare in our model is associated with trade costs in a similar way but under a very different context. Our model incorporates these two effects, but adds a tradeoff between efficient vertical pricing and parallel trade. Without parallel imports, the wholesale price would equal true marginal cost of supplying the good to the distributor. Parallel imports force the manufacturer to raise the wholesale price above marginal cost, which creates a distortion in the vertical pricing scheme. This adds additional cost to cross-hauling costs and both must be compared to gains from reducing consumer price in the importing country.

To see the intuition of why global surplus can increase in cost $g$, notice that when

$g>\frac{3}{14} a, M$ will set $w$ high enough so that it is not profitable for $L$ to sell back. A higher $g$ will enable $M$ to set a lower $w$ to achieve this objective. In turn,a lower $w$ reduces the price distortion in market $B$ and thus increases social surplus.

Thus, if there is parallel trade in equilibrium, then a reduction in the cost of conducting parallel trade increases social welfare. On the other hand, if parallel trade is currently being deterred by the manufacturer throught its choice of vertical pricing, then a reduction in the cost of conducting parallel trade actually decreases social welfare. To the extent that the cost of conducting parallel trade is affected by government regulations and trade policies, our result suggests that an optimal policy is one that either reduces $g$ as much as possible or raises $g$ as much as possible, but not to leave $g$ at some intermediate value.

\section{3b. The Effects of Restricting Parallel Imports}

If $L$ is prevented from selling the product back to $A$, either because there exists effective vertical restraint imposed by $M$ or because parallel imports are not legally allowed, then again with a contract $(w, T)$, and denoting equilibrium (optimal) variables by adding superscript " $v$ ", it is optimal for $M$ to set: 
$w^{v}=c=0$, and $T^{v}=\pi_{b}^{o}=\frac{1}{4}$.

Prices in $A$ and $B$ will then be

$$
p_{a}^{v}=\frac{a}{2}, p_{b}^{v}=\frac{1}{2} .
$$

Since, when there is parallel importing, $p_{a}^{*}=\frac{5 a+7 g}{13}<\frac{a}{2}$ and $p_{b}^{*}=\frac{1}{2}+\frac{a+4 g}{13}>\frac{1}{2}$, we have

Proposition 3 Restricting parallel imports raises prices in the country receiving parallel imports and reduces prices in the country where parallel imports originate. In other words, restricting parallel imports hurts consumers in the country receiving parallel imports but benefits consumers in the country where parallel imports originate.

Combined industry profit in the two countries will be

$$
\Pi^{v}=\frac{1}{4}\left(a^{2}+1\right) .
$$

Since $\Pi^{*}<\frac{1}{4}\left(a^{2}+1\right)$. for $g<\frac{a}{2}$, the manufacturer always benefits if parallel imports are prohibited.

The combined social surplus in two countries if parallel imports are not allowed is

$$
S^{v}=\frac{1}{2}\left(\frac{a}{2}\right)^{2}+\frac{1}{2}\left(\frac{1}{2}\right)^{2}+\frac{1}{4}\left(a^{2}+1\right)=\frac{3}{8}\left(a^{2}+1\right) .
$$

The change in social surplus due to restricting parallel imports is

$$
\Delta S \equiv S^{v}-S^{*}= \begin{cases}-\frac{5}{104} a^{2}+\frac{6}{13} a g-\frac{23}{26} g^{2}+\frac{1}{26} a+\frac{2}{13} g & \text { if } g \leq \frac{3}{14} a \\ \frac{1}{32}(a-2 g+4)(a-2 g) & \text { if } g>\frac{3}{14} a\end{cases}
$$

We have:

Proposition 4 Restricting parallel imports may either increase or reduce combined social surplus in two countries. For any given $a>\frac{4}{5}$, there exists a unique number 
$g(a) \in\left(0, \frac{3}{14} a\right]$ such that restricting parallel imports reduces social surplus if $g<g(a)$ and increases social surplus if $g>g(a)$. If $g>\frac{3}{14} a$, then restricting parallel imports always increases combined social surplus.

Proof. Notice first that $\Delta S>0$ if $g>\frac{3}{14} a$.

Next, since $S^{*}=\frac{11}{26} a^{2}+\frac{3}{8}-\frac{1}{26} a$ when $g=0$ and $S^{*}=\frac{3}{8}\left(a^{2}+1\right)=S^{v}$ when $g=\frac{a}{2}$, and since

$$
\frac{3}{8}\left(a^{2}+1\right)-\left(\frac{11}{26} a^{2}+\frac{3}{8}-\frac{1}{26} a\right)=-\frac{1}{104} a(5 a-4) \lesseqgtr 0 \text { iff } a \lesseqgtr \frac{4}{5},
$$

we have $\Delta S<0$ if $g=0$ and $a>\frac{4}{5}$.

But since $S^{*}$ decreases in $g$ for $g \leq \frac{3}{14} a$ and $S^{v}$ is independent of $g, \Delta S$ increases in $g$ for $g \leq \frac{3}{14} a$. Therefore, for any $a>\frac{4}{5}$, there must exist a unique $g(a) \in\left(0, \frac{3}{14} a\right]$ such that $\Delta S<0$ when $g<g(a), \Delta S=0$ when $g=g(a)$, and $\Delta S>0$ when $g>g(a)$.

It is then obvious that restricting parallel imports may either increase or reduce the combined social surplus in two countries.

Whether parallel importing should be established as a global policy is under debate in the WTO. Our analysis can shed light on this issue. Our finding that parallel importing can increase world welfare in some situations but reduce world welfare in other situations suggests that neither a policy that always bans parallel trade nor a policy that always facilitates it is justified from the perspective of economic efficiency. Rather, a rule of reason concerning the legal status of parallel imports or vertical restraints by manufacturers to prevent them seems economically warranted. Our analysis further suggests that policy choices concerning parallel imports are closely related to choices on other trade policies. For instance, if it is desirable that parallel imports be legally allowed, then it would also be desirable to reduce any trade barrier that increases the cost of parallel trading. On the other hand, if the cost of conducting parallel imports is sufficiently high, part of which could be due to the presence of 
significant trade barriers, then it could be desirable not to allow parallel imports legally.

\section{Empirical Evidence and Policy Implications}

Customs authorities do not collect data on parallel imports, making systematic empirical analysis of such trade flows impossible. We first review survey evidence on the subject, noting the multiple causes and some puzzles that our model can explain. We then perform an econometric analysis of price data that is aimed at testing key implications of the model.

\section{4a. Survey Evidence on Parallel Imports}

The limited evidence available suggests that there are multiple causes of parallel trade. Parallel imports (or gray-market imports) became an issue of active policy concern in the United States around 1984. Survey evidence reported rapidly rising parallel import volumes in 37 product categories, with most being high-end goods bearing recognized trademarks, such as Mercedes-Benz sedans, Opium perfume, and Nikon cameras (USDOC, 1985). As Tarr (1985) and Hilke (1988) point out, this surge in parallel imports corresponded to a strong rise in the real effective value of the dollar. Dollar-denominated U.S. real prices within authorized distribution outlets

did not fall in this period (indeed, many rose), suggesting strongly that foreign manufacturers were pricing to market in dollar terms. This lagged (or absent) adjustment to the exchange rate change posits one primary determinant of parallel imports: international price differences associated with limited international pass-through effects (Feenstra, 1989; Kasa, 1992).

Free-riding behavior was less evident in the 1980s. Only Opium perfume reported significant parallel imports prior to the dollar appreciation and the rise in its dollar- 
denominated marketing costs was far less than the exchange-rate change (Tarr, 1985; Hilke, 1988). Notice that while many of the parallel imports involve name-brand consumer goods for which service and promotional activities are likely to be important, it does not necessarily mean that there will be inefficient free riding on these activities. For instance, a manufacturer may itself engage in the promotional activities and internalize their benefits for all distributors. Or, a distributor may be able to charge for the service it provides and thus internalize its benefits.

Parallel imports attract attention in the EU, which maintains regional exhaustion and is considering whether to adopt international exhaustion in trademarks. A recent survey indicates that intra-union parallel trade captures varying shares of sales in ten sectors, as shown in Table 2 (NERA, 1999)..$^{13}$ Parallel imports take their largest shares in compact disks, cosmetics and perfumes, and soft drinks. Survey respondents also predict modest rises in parallel imports from outside the EU if international exhaustion were adopted, though the increases in market share for parallel traders in footwear, consumer electronics, and domestic appliances could be significant. (See Table 2.)

It is interesting that this study identifies as likely sources for rising parallel imports certain countries that may have higher retail prices than those in the EU for the goods involved. For example, comparing retail prices of specific large-engine passenger vehicles in 1993, we calculate that the average Japanese price exceeded the average price in the EU by 23 percent. ${ }^{14}$ This provides some evidence to support our explanation of parallel imports based on the problem of veritcal price control. An important implication of our model is that parallel imports can flow from a country with higher retail prices to a country with lower retail prices. This possibility

\footnotetext{
${ }^{13}$ This survey garnered an extremely low response rate and numerical evidence presented should be treated with caution. It seems likely that the true extent of parallel trade is underreported.

${ }^{14}$ These computations were made from retail transactions prices listed in the International Comparisons Project performed by the United Nations. They were provided to us by the World Bank.
} 
is mentioned in the literature as well. Barfield and Groombridge (1998) explicitly mention that imperfect competition in distribution could be consistent with parallel imports coming from high-price markets. Further, a survey of US exporters to Asia in 1989 indicated that some distributor agents experienced competition from US suppliers, which may have sold products on the American market at higher retail prices than those commanded in Asia (Palia and Keown, 1991). Finally, respondents to the NERA (1999) survey identified ex-factory (eg, wholesale) price differences across markets as a major determinant of parallel trade.

\section{4b. Econometric Analysis of International Prices}

We wish to provide meaningful econometric analysis of our vertical-pricing model. Although we do not have data on quantities of parallel imports, we nevertheless can use regression analysis of international wholesale prices to test indirectly the model's implications. In particular, our regression analysis is motivated by the following two considerations. First, according to equation (7) from Proposition 1, the equilibrium wholesale price set by the manufacturer has an inverted U-shape: it first increases and then decreases in the cost of engaging in parallel importing. In the context of the model, the tariff rate in the home nation of the manufacturer is an ideal measure of this cost because the manufacturer is concerned with foreign wholesalers re-exporting goods back to the source country. Indeed, except for the theory in this paper, there seems to be no other reason why the foreign wholesale price set by the manufacturer should depend on the home tariff rate.

Second, a slight extension of our model would show that if the manufacturer sells its product through several independent wholesalers in a foreign country, then competition among those wholesalers would enable the manufacturer to raise its wholesale price without worsening the distortion arising from the double markup. The manufacturer would set a higher wholesale price in competitive markets, which would reduce 
parallel imports with smaller distortion in vertical pricing. We test this proposition by regressing wholesale prices on a measure of concentration in wholesale trade in each export market. We expect to find a negative coefficient.

A satisfactory empirical environment in which to test our model is one in which a single manufacturer sets varying wholesale prices in different export markets. For this purpose, we employ U.S. export prices in 26 highly disaggregated (10-digit Harmonized System classification) products that may be thought subject to parallel trade. We equate wholesale prices in each export market with U.S. export unit values to each country. Note that international trade prices should adequately reflect wholesale prices because substantial amounts of trade occur through distributors. In 1994, for example, 46 percent of U.S. intrafirm exports over all industries was shipped to foreign wholesalers. ${ }^{15}$ We focus on two definitions of wholesale price. First, export prices themselves reflect pricing decisions at the U.S. border. Second, we adjust export prices for the costs of ad valorem transport costs and tariffs in the importing nations. These latter prices reflect marginal costs as seen by local agents.

The export unit value data come from extensively disaggregated commodity classifications, but it is inevitable that the products shipped to various markets are not identical. We control for this source of error in two ways. First, we exclude from the analysis any country for which the export price is greater than 250 percent of the median price or less than 40 percent of the median. Such extreme prices invariably reflected small export quantities. Second, we include in the regression the number of product sub-categories in each of our 10-digit categories. This variable provides a control for product heterogeneity within each product class. The 26 categories we use and the number of countries per category are listed in the Appendix, Table 1.

We adopt the following pair of regression equations:

$$
w_{i j}=\alpha+\beta_{1} Y_{j}+\beta_{2} H_{i}+\beta_{3} C_{i j}+\beta_{4} T U_{i}+\beta_{5} T U_{i}^{2}
$$

\footnotetext{
${ }^{15}$ Compiled by the authors from Survey of Current Business, February 1997.
} 


$$
e_{i j}=a+b_{1} Y_{j}+b_{2} H_{i}+b_{3} C_{i j}+b_{4} T U_{i}+b_{5} T U_{i}^{2}+b_{6} T_{i j}+b_{7} \tau_{i j}
$$

In the first equation, $w$ is the wholesaler marginal cost for product $i$ in importer $j$. In the second equation, $e$ is the U.S. export price at the border. These prices are related by $w_{i j}=e_{i j}\left(1+T_{i j}\right)\left(1+\tau_{i j}\right)$ where $T$ indicates the ad valorem tariff rate in the importing nation and $\tau$ is the estimate of percentage transport costs. Thus, in the first equation we explain the structure of wholesaler marginal costs across countries. In the second equation we explain the structure of export prices set by the manufacturer at the port but control for the fact that these prices would depend negatively on import tariffs and transport costs to the extent the exporter must absorb some portion of these charges. Percentage transport costs are estimated from differences in the bilateral values of U.S. imports from eachmarket, measured with and without charges for cost, insurance, and freight (CIF). The variable $\mathrm{Y}$ is per-capita income in the importing country, which we hypothesize has a positive coefficient if it reflects demand size. The variable $\mathrm{H}$ is our measure of product heterogeneity. We anticipate its sign to be positive if more differentiated products bear higher prices. Concentration in the wholesale market is captured by $\mathrm{C}$, which is the Herfindahl index for wholesale trade in each importing country, disaggregated by corresponding SIC category. Again, we anticipate the sign on $\mathrm{C}$ in both equations to be negative. Finally, TU is the U.S. ad valorem tariff rate. Our theory predicts a positive sign on the linear term and a negative sign on the quadratic term in both equations.

In the regressions we also incorporate regional dummy variables, with regions defined as the European Union, other Europe, Canada, Mexico and Central America, South America, East Asia, and other developing countries. We exclude the dummy variable for the EU, making it the reference case. There are two reasons for including the regional slope dummies. First, we wish to control for idiosyncratic pricing decisions associated with regions. Second, and of greater interest, our model suggests that the exporting manufacturer would set a higher price in countries or regions that 
permit parallel exports back to the United States. In our country sample, such exports are prohibited by the EU, other Europe, Canada, and Mexico. Parallel trade is permitted by most countries of East Asia, including Japan, and by most developing countries in other regions.

Sources for our data are as follows. The export unit-value data and CIF rates for 1993 were taken from CD-ROMS compiled by Feenstra $(1996,1997)$. The number of product sub-categories within each 10-digit HS category was taken from the U.S. National Trade Data Bank. Tariff rates by HS product category were provided by the World Bank. Herfindahl indexes were calculated from firm-specific sales data in each country (covering both domestic and foreign-owned distributors), available from a private service called infoUSA. Herfindahl indexes could not be constructed because of missing data in a number of product-country pairs, primarily in developing countries. Thus, we have two data samples, one including Herfindahl indexes (522 observations) and one excluding Herfindahl indexes (972 observations). Correlation coefficients among the key variables in the smaller sample are provided in the Appendix, Table 2 .

Table 3 presents our regression results, performed with ordinary least squares but the standard errors are adjusted to be heteroskedastic-consistent. ${ }^{16}$ The first two columns use the wholesaler marginal cost as the dependent variable and the third and fourth columns use export price. In each pair, the first equation includes the importer Herfindahl index in wholesale distribution while the second one excludes it. Thus, the second equation of each pair incorporates more observations, primarily from developing countries. Consider first the determination of wholesaler marginal costs, which incorporates by construction import tariffs and transport costs. Our first result is that GDP per capita exerts a negative influence on wolesale cost, which is

\footnotetext{
${ }^{16}$ Because the list of products covers goods with widely divergent median unit prices, the presence of heteroskedasticity is likely.
} 
surprising in that we would expect higher prices in markets with stronger demand. It is conceivable that a better measure of demand would be aggregate market size. One partial explanation for this puzzle may be seen from the coefficient on the Herfindahl index. As our theory predicts, more concentrated distribution markets experience lower wholesale prices because U.S. manufacturers have additional power to control vertical pricing decisions and to deter parallel imports. As the correlation table in the Appendix shows, there is a strong negative correlation between GDP per capita and market concentration. However, when the Herfindahl index is excluded, the coefficient on GDP per capita is cut in half and becomes much less significant. Thus, without conditioning on local market power of distributors, the marginal costs of acquiring U.S. manufactures seems little affected by per-capita income.

The control for product heterogeneity has a positive coefficient, as anticipated. Thus, categories that comprise more kinds of differentiated goods tend to have higher wholesale prices, other things equal.

A key finding is that the U.S. tariff rate, a measurable component of the costs of parallel-exporting goods back from distributor markets abroad to the United States, operates as predicted by the theory. Specifically, there is an inverted quadratic relationship between wholesale marginal costs and the U.S. tariff rate by product category. Thus, for products with low tariff rates, U.S. exporters set foreign marginal costs that rise with those rates in order to deter re-imports of parallel goods. But for products with high tariff rates, U.S. exporters set marginal costs that fall as tariff charges increase. Again, it is difficult to find reason outside our model why foreign prices should depend systematically on domestic tariff rates

Most of the regional dummy variables are insignificant, suggesting that there is little systematic variation in price behavior relative to the prices set in the European Union. The major exception is that prices in East Asia are significantly higher than those in other regions of the world. Except for Japan, these countries have lower average 
incomes than those in the EU, so this difference seems unlikely to be due to demand elasticity. Some of the difference evidently reflects higher tariffs and transport charges, because the coefficients are somewhat smaller in the third and fourth columns where the focus is strictly on export prices. However, those differences remain statistically significant and large. Within the context of our model, this result is consistent with the need of U.S. manufacturers to set high wholesale distribution prices in East Asian economies in order to preclude parallel exporting back to the United States. These countries generally permit such exports and are frequently the subject of complaints from U.S. manufacturers in this regard.

Turning to the export-price regressions we again find that local market concentration significantly reduces the export prices set at the U.S. border by American manufacturers. This is entirely consistent with our vertical-control approach to the sources of parallel trade. Further, the U.S. tariff rate continues to be significant in both its linear and quadratic terms. Tariff rates in the importing country and transport costs to move products there have a significantly negative impact on export prices, suggesting that U.S. exporting firms absorb some component of those costs. Finally, only the East Asian dummy variable is significant and its positive sign again provides indirect support for our theory. (See Table 3.)

\section{Conclusion}

This paper has reviewed the debates and the international policy structure concerning parallel imports and has offered a theory of parallel imports as it relates to vertical price control. We find that while the possibility of parallel imports can increase retail-market competition, it can also affect a marnufacturer or rights owner's incentive in setting the wholesale price it charges a distributor and reduce vertical pricing efficiency. There exists a U-shaped welfare curve of parallel trade with respect to trade cost, and parallel trade is more likely to increase welfare within a 
region than in the entire world trading system. Existing and additional empirical evidence supports the view that there are multiple causes for parallel imports. While these theories differ in their precise policy implications, they all appear to suggest that some restrictions on parallel imports, especially between countries with very different demands or high trade costs, would be desirable. Our analysis also suggests a need to coordinate international policy towards parallel imports with other trade policies.

Our econometric analysis of prices suggests that our theoretical explanation of parallel imports is relevant and conceivably a significant element of global trade. It also supports the importance of the theoretical analysis for the policy debates about parallel imports. For example, our analysis suggests that given any two countries, there exists some critical value of trade costs such that parallel trade increases (or decreases) global welfare when the cost of engaging it is below (or above) the critical value. Pricing behavior by U.S. exporters in the face of low American tariffs suggests that they increase export prices in an attempt to deter parallel trade. But in the presence of low trade costs our analysis suggests that allowing parallel imports is likely to increase welfare. This may be particularly true within a region, such as the Euopean Union or NAFTA. However, restricting parallel imports may be desirable between countries involving significant trade costs. Interestingly, Malueg and Schwartz (1994) offer a similar policy implication, although for a different reason.

To the extent that parallel imports may allow one distributor to free ride on another distributor's promotional activities and reduce efficiency of promotional activities, a case may be made for the prevention of parallel imports. Our analysis suggests that there need not be externalities of this type in order to have welfare-improving restrictions on parallel imports. The need to achieve vertical price efficiency by a manufacturer can make it desirable to prevent parallel imports. Recently, concern about parallel trade has surfaced in pharmaceuticals and biotechnology, on the one 
hand, and the copyright industries including software, recorded music, videos, and book publishing, on the other. These sectors are characterized by high $\mathrm{R} \& \mathrm{D}$ costs but low marginal costs of production and distribution. Thus, the differences between retail prices and marginal costs for these products are often significant. Our theory may prove to be particularly useful in these situations.

There are a number of possible extensions of the model and its interpretations. We could allow general demand functions in both countries. Explicit solutions would not be possible in general, but the insights of the paper would not be changed. Again, the manufacturer would face the tradeoff between achieving vertical pricing efficiency and preventing parallel imports. We could also imagine retailers incurring fixed selling costs in each country. In the presence of selling costs, parallel imports may cause a manufacturer to refrain from selling in a particular country at all. Thus, such costs would make restricting parallel imports more likely to increase the combined social surplus in two countries. Clearly, such extensions would increase the complexity of the processes underlying parallel imports and would call for additional empirical analysis. 


\section{REFERENCES}

[1] Abbott, F.M., 1998, First report (final) to the committee on international trade law of the international law association on the subject of parallel importation, Journal of International Economic Law 1, 607-636.

[2] Barfield, C.E. and M.A. Groombridge, 1998, The economic case for copyright owner control over parallel imports, The Journal of World Intellectual Property 1, 903939.

[3] Brander, J. and P. Krugman, 1983, A reciprocal dumping model of international trade, Journal of International Economics 15, 313-321.

[4] Cavusgil, S.T. and E. Sikora, 1988, How multinationals can counter gray market imports, Columbia Journal of World Business 23, 75-85.

[5] Cespedes, F.V., E.R. Corey, and V.K. Rangan, 1988, Gray markets: causes and cures, Harvard Business Review 88, 75-82.

[6] Chard, J.S. and C.J. Mellor, 1989, Intellectual property rights and parallel imports, World Economy 12, 69-83.

[7] Chen, Y., 1999, Oligopoly price discrimination and resale price maintenance, RAND Journal of Economics, 30, 441-455.

[8] Contractor, Farok, 1981, International technology licensing: compensation, costs, and negotiation, (New York: Lexington Books).

[9] Danzon, P.M., 1997, Pharmaceutical price regulation, (Washington: The AEI Press).

[10] Feenstra, R.C., 1989, Symmetric pass-through of tariffs and exchange rates under imperfect competition: an empirical test, Journal of International Economics $27,25-46$. 
[11] Feenstra, R.C., 1996, US imports, 1972-1994: data and concordances, National Bureau of Economic Research, working paper 5515.

[12] Feenstra, R.C., 1997, US exports, 1972-1994: with state exports and other US data, National Bureau of Economic Research, working paper 5990.

[13] Francois, J.F., B. McDonald, and H. Nordstrom, 1996, The Uruguay Round: a numerically based qualitative assessment, in W. Martin and L.A.Winters, editors, The Uruguay Round and the Developing Countries, (Cambridge: Cambridge University Press), 253-291.

[14] Hilke, J.C., 1988, Free trading or free riding: an examination of the theories and available evidence on gray market imports, World Competition 32, 75-92.

[15] Kasa, K., 1992, Adjustment costs and pricing-to-market: theory and evidence, Journal of International Economics 32, 1-30.

[16] Katz, M., 1989, Vertical contractual relations, in R. Schmalensee and R. Willig, eds, The Handbook of Industrial Organization. (New York: North-Holland).

[17] Malueg, D.A. and M. Schwartz, 1994, Parallel imports, demand dispersion, and international price discrimination, Journal of International Economics 37, 167-196.

[18] Maskus, K.E., 1998, Intellectual property rights in the World Trade Organization: progress and prospects, in J.J. Schott, editor, Launching New Global Trade Talks: An Action Agenda, (Washington: Institute for International Economics), 133-150.

[19] National Economic Research Associates, 1999, The economic consequences of the choice of regime in the area of trademarks, (London: NERA). 
[20] Organization for Economic Cooperation and Development, 1994, Consumption tax trends (Paris: OECD).

[21] Palia, A.P. and C.F. Keown, 1991, Combating parallel importing: views of U.S. exporters to the Asian-Pacific region, International Marketing Review 8, 47-56.

[22] Tarr, D.G., 1985, An economic analysis of gray market imports, U.S. Federal Trade Commission, manuscript.

[23] United States Department of Commerce, 1985, Economic effects of parallel imports: a preliminary analysis, Patent and Trademark Office, manuscript. 
Table 1. Summary of IPR Exhaustion Regimes

$\begin{array}{rrrr}\text { Country } & \text { Trademarks } & \text { Patents } & \text { Copyrights } \\ \text { EU } & \text { Community Exhaustion } & \text { Community Exhaustion } & \text { Community Exhaustion } \\ \text { US } & \begin{array}{r}\text { National Exhaustion limited by } \\ \text { common control and no } \\ \text { consumer confusion }\end{array} & \text { National Exhaustion } & \text { National Exhaustion } \\ \text { Japan } & \begin{array}{r}\text { International Exhaustion } \\ \text { unless agreed by contract or }\end{array} & \text { Same as Trademarks } & \text { International Exhaustion } \\ & & & \text { except for motion pictures }\end{array}$
original sale is price-controlled except for motion pictures sold by patent owner without clear restrictions

\author{
National Exhaustion \\ except for compact disks \\ and books
}

Sources: NERA (1999) and International Intellectual Property website, 1998. 
Table 2. Survey Estimates of Parallel Imports

\begin{tabular}{|c|c|}
\hline Sector & Estimate \\
\hline Footwear and leather goods & $<5 \%$ \\
\hline Musical recordings & $10-20 \%$ \\
\hline Automobiles & $<5 \%$ \\
\hline Consumer electronics & $5 \%$ \\
\hline Domestic appliances & $<5 \%$ \\
\hline Cosmetics and perfumes & up to $13 \%$ \\
\hline Clothing & $5-10 \%$ \\
\hline Soft drinks & up to $15 \%$ \\
\hline Confectionery & $<10 \%$ \\
\hline Alcoholic drinks & $<5 \%$ \\
\hline
\end{tabular}

Source: NERA (1999)
Within the European

Union

Additional PI with

Unilateral Exhaustion

$5 \%$

$4 \%$

$<5 \%$

$10 \%$

$8 \%$

$<5 \%$

$1.50 \%$

$<5 \%$

$5 \%$

Negligible
Likely Sources

SE Asia

US, Japan, SE Asia

Japan

Japan, East Asia

US

US

SE Asia, US

na

US

na 
Table 3. Estimation of Vertical-Pricing Model

\begin{tabular}{|c|c|c|c|c|}
\hline Variable & Wholesaler MC & Wholesaler MC & Export Price & Export Price \\
\hline Constant & $\begin{array}{r}-339.5 \\
(-0.19)\end{array}$ & $\begin{array}{r}-3411 \\
(-2.49)\end{array}$ & $\begin{array}{r}51.5 \\
(0.03)\end{array}$ & $\begin{array}{r}-2405 \\
(-2.10)\end{array}$ \\
\hline GDPPC & $\begin{array}{r}-0.249 \\
(-2.60)\end{array}$ & $\begin{array}{r}-0.13 \\
(-1.64)\end{array}$ & $\begin{array}{r}-0.17 \\
(-2.13)\end{array}$ & $\begin{array}{r}-0.09 \\
(-1.36)\end{array}$ \\
\hline Heterogeneity & $\begin{array}{r}4244 \\
(9.28)\end{array}$ & $\begin{array}{r}3814 \\
(10.67)\end{array}$ & $\begin{array}{r}3200 \\
(9.49)\end{array}$ & $\begin{array}{r}2970 \\
(10.85)\end{array}$ \\
\hline Herfindahl & $\begin{array}{r}-4104 \\
(-3.70)\end{array}$ & & $\begin{array}{r}-3555 \\
(-3.98)\end{array}$ & \\
\hline US Tariff & $\begin{array}{r}354161 \\
(7.11)\end{array}$ & $\begin{array}{l}381567 \\
(12.29)\end{array}$ & $\begin{array}{r}329115 \\
(7.36)\end{array}$ & $\begin{array}{l}332717 \\
(12.00)\end{array}$ \\
\hline US Tariff Sq & $\begin{array}{r}-0.56 e+7 \\
(-7.32)\end{array}$ & $\begin{array}{r}-0.59 e+7 \\
(-12.19)\end{array}$ & $\begin{array}{r}-0.53 e+7 \\
(-7.64)\end{array}$ & $\begin{array}{r}-0.52 \mathrm{e}+7 \\
(-11.96)\end{array}$ \\
\hline Importer Tariff & & & $\begin{array}{r}-3960 \\
(-2.26)\end{array}$ & $\begin{array}{r}-3622 \\
(-2.57)\end{array}$ \\
\hline Transport Cost & & & $\begin{array}{r}-3682 \\
(-2.33)\end{array}$ & $\begin{array}{r}-1488 \\
(-1.48)\end{array}$ \\
\hline Europe Other & $\begin{array}{l}-476.4 \\
(-0.52)\end{array}$ & $\begin{array}{r}-1396 \\
(-1.64)\end{array}$ & $\begin{array}{l}-474.4 \\
(-0.59)\end{array}$ & $\begin{array}{r}-1337 \\
(-1.74)\end{array}$ \\
\hline Canada & $\begin{array}{l}-279.1 \\
(-0.22)\end{array}$ & $\begin{array}{r}13.1 \\
(0.01)\end{array}$ & $\begin{array}{l}-583.9 \\
(-0.51)\end{array}$ & $\begin{array}{l}-167.6 \\
(-0.15)\end{array}$ \\
\hline Mex/Central Am & $\begin{array}{l}-953.3 \\
(-0.54)\end{array}$ & $\begin{array}{r}-2418 \\
(-2.08)\end{array}$ & $\begin{array}{l}-279.9 \\
(-0.19)\end{array}$ & $\begin{array}{r}-1779 \\
(-1.90)\end{array}$ \\
\hline South America & $\begin{array}{r}-72.6 \\
(-0.04)\end{array}$ & $\begin{array}{r}-1387 \\
(-1.25)\end{array}$ & $\begin{array}{r}-31.0 \\
(-0.02)\end{array}$ & $\begin{array}{r}-1170 \\
(-1.33)\end{array}$ \\
\hline East Asia & $\begin{array}{r}3676 \\
(3.41)\end{array}$ & $\begin{array}{r}1920 \\
(2.25)\end{array}$ & $\begin{array}{r}2978 \\
(3.19)\end{array}$ & $\begin{array}{r}1334 \\
(1.78)\end{array}$ \\
\hline Other Developing & $\begin{array}{r}-1610 \\
(-0.94)\end{array}$ & $\begin{array}{r}-1924 \\
(-1.45)\end{array}$ & $\begin{array}{r}-1079 \\
(-0.80)\end{array}$ & $\begin{array}{r}-1448 \\
(-1.40)\end{array}$ \\
\hline $\begin{array}{l}\text { Sample size } \\
\text { Adjusted } \mathrm{R}^{2} \\
\mathrm{~F}\end{array}$ & $\begin{array}{l}522 \\
0.29 \\
20.3\end{array}$ & $\begin{array}{l}972 \\
0.26 \\
35.7\end{array}$ & $\begin{array}{r}522 \\
0.26 \\
14.8\end{array}$ & $\begin{array}{r}972 \\
0.24 \\
27.2\end{array}$ \\
\hline
\end{tabular}

Figures in parentheses are t-statistics. Standard errors are heteroskedastic-consistent. 
Appendix Table 1. Products Used in the Regression Analysis

$\begin{array}{llc}\text { HS number } & \text { Product } & \text { Number of Countries } \\ 2208306020 & \text { Bourbon whiskies } & 43 \\ 2208309020 & \text { Whiskies except bourbon } & 32 \\ 4901910020 & \text { Dictionaries } & 23 \\ 4901990075 & \text { Rack size paperbacks } & 48 \\ 4902902040 & \text { Business periodicals } & 38 \\ 8414400000 & \text { Air compressors 1 } & 32 \\ 8414801018 & \text { Air compressors 2 } & 24 \\ 8414801042 & \text { Air compressors 3 } & 35 \\ 8414801067 & \text { Air compressors 4 } & 36 \\ 8414801075 & \text { Air compressors 5 } & 27 \\ 8414801080 & \text { Air compressors 6 } & 29 \\ 8415100040 & \text { Air conditioners 1 } & 50 \\ 8415100060 & \text { Air conditioners 2 } & 54 \\ 8415100080 & \text { Air conditioners 3 } & 50 \\ 8415810010 & \text { Air conditioners 4 } & 41 \\ 8415810030 & \text { Air conditioners 5 } & 39 \\ 8415820005 & \text { Air conditioners 6 } & 35 \\ 8415820010 & \text { Air conditioners 7 } & 33 \\ 8415820015 & \text { Air conditioners 8 } & 35 \\ 8524904040 & \text { Laser disk sound recordings } & 49 \\ 8528104000 & \text { Video recorders } & 37 \\ 8528108005 & \text { Color televisions } & 31 \\ 8703240050 & \text { 4-cylinder automobiles } & 31 \\ 8703240060 & \text { 6-cylinder automobiles } & 53 \\ 8711500000 & \text { Motorcycles } & 40 \\ 900653000 & \text { Professional photo cameras } & 27\end{array}$

Appendix Table 2: Correlations among Variables

$\begin{array}{lllllllll} & \text { wprice } & \text { eprice } & \text { gdppc } & \text { het } & \text { herf } & \text { ustar } & \text { tariff } & \text { transport } \\ \text { wprice } & 1.00 & & & & & & & \\ \text { eprice } & 0.97 & 1.00 & & & & & & \\ \text { gdppc } & -0.16 & -0.09 & 1.00 & & & & & \\ \text { het } & 0.46 & 0.43 & -0.05 & 1.00 & & & & \\ \text { herf } & -0.06 & -0.11 & -0.34 & -0.07 & 1.00 & & & \\ \text { ustar } & 0.13 & 0.14 & -0.05 & 0.04 & -0.09 & 1.00 & & \\ \text { tariff } & 0.27 & 0.16 & -0.51 & 0.23 & 0.27 & 0.14 & 1.00 & \\ \text { transport } & -0.11 & -0.14 & -0.00 & -0.16 & 0.15 & -0.18 & -0.02 & 1.00\end{array}$

Notes: wprice is wholesaler marginal cost, eprice is export price, gdppc is GDP per capita, het is the measure of product heterogeneity, herf is the Herfindahl index, ustar is the U.S. tariff rate, tariff is the tariff rate in the importing country, and transport is percentage transport costs from the U.S. to the importing country. Sample size for these correlations is 522 . 


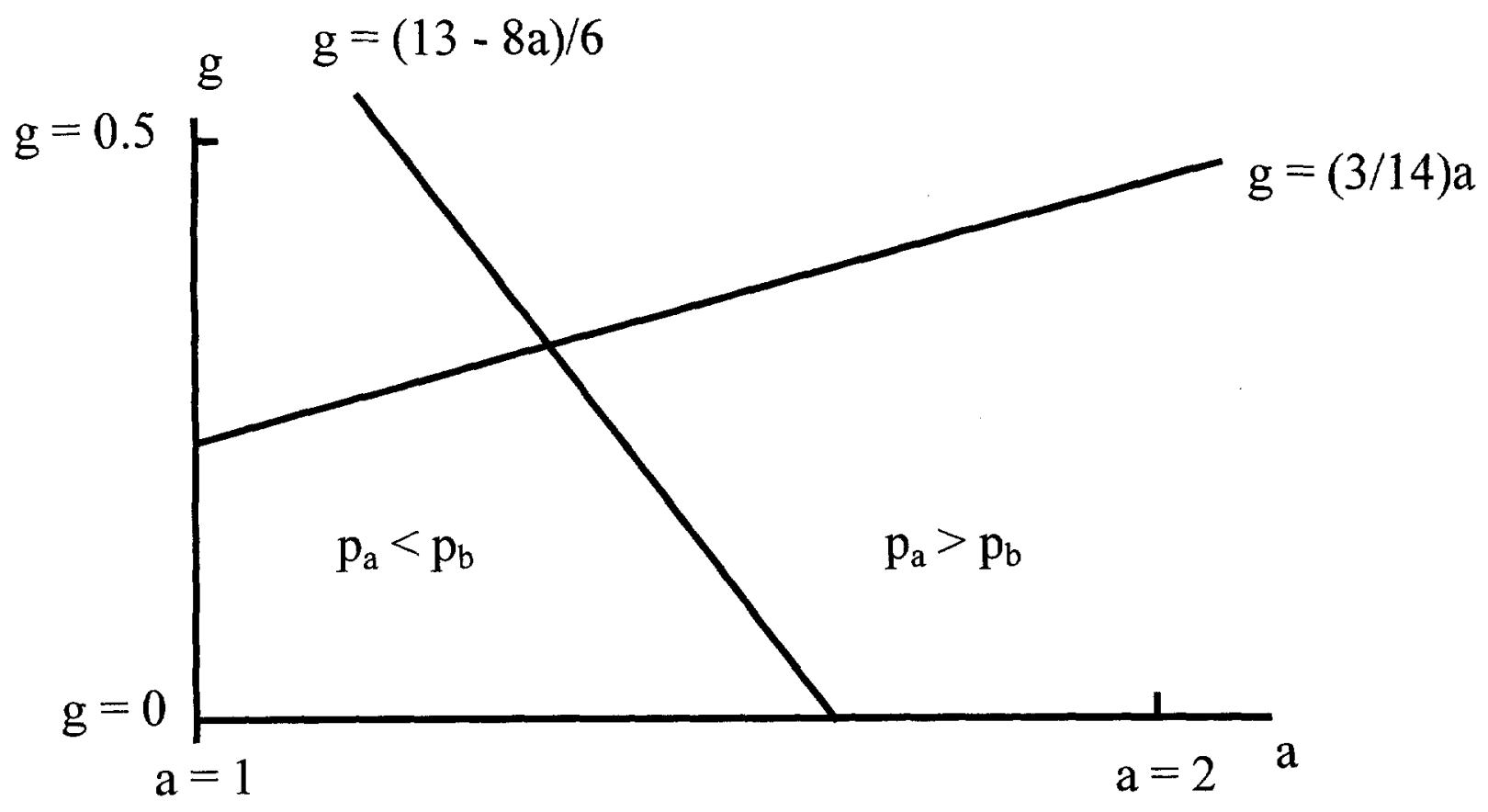

Figure 1: Parallel Imports and Trading Costs 



\section{Policy Research Working Paper Series}

Title

WPS2442 A Firms's-Eye View of Policy and Fiscal Reforms in Cameroon

WPS2443 The Politics of Economic Policy Reform in Developing Countries

WPS2444 Seize the State, Seize the Day: State Capture, Corruption, and Influence in Transition

WPS2445 Subsidies in Chilean Public Utilities

WPS2446 Forecasting the Demand for Privatized Transport: What Economic Regulators Should Know, and Why

WPS2447 Attrition in Longitudinal Household Survey Data: Some Tests for Three Developing-Country Samples

\section{WPS2448 On "Good" Politicians and "Bad" Policies: Social Cohesion, Institutions, and Growth \\ WPS2449 Pricing Irrigation Water: A Literature Survey}

WPS2450 Which Firms Do Foreigners Buy? Evidence from the Republic of Korea

WPS2451 Can There Be Growth with Equity? Klaus Deininger An Initial Assessment of Land Reform Julian May in South Africa

WPS2452 Trends in Private Sector Development Shobhana Sosale in World Bank Education Projects

WPS2453 Designing Financial Safety Nets to Fit Country Circumstances

WPS2454 Political Cycles in a Developing Economy: Effect of Elections in Indian States
Edward J. Kane

Bernard Gauthier
Isidro Soloaga
James Tybout

Richard H. Adams Jr.

Joel S. Hellman

Geraint Jones

Daniel Kaufmann

Pablo Serra

Lourdes Trujillo

Emile Quinet

Antonio Estache

Harold Alderman Jere R. Behrman Hans-Peter Kohler John A. Maluccio Susan Cotts Watkins

Jo Ritzen

William Easterly

Michael Woolcock

Robert C. Johansson

Caroline Freund

Simeon Djankov

Stuti Khemani
September 2000

33766

September 2000

S. Sosale 36490

September 2000

\section{Contact} for paper

L. Tabada 36896

M. Coleridge-Taylor 33704

D. Billups 35818

G. Chenet-Smith 36370

G. Chenet-Smith 36370

P. Sader 33902

A. Kibutu

M. Williams 87297

R. Vo 33722

K. Labrie 31001

September 2000

37698 


\section{Policy Research 'Norking Paper Series}

\begin{tabular}{|c|c|c|c|c|}
\hline & Title & Author & Date & $\begin{array}{l}\text { Contact } \\
\text { for paper }\end{array}$ \\
\hline WPS2455 & $\begin{array}{l}\text { The Effects on Growth of Commodity } \\
\text { Price Uncertainty and Shocks }\end{array}$ & Jan Dehn & September 2000 & $\begin{array}{l}\text { P. Varangis } \\
33852\end{array}$ \\
\hline WPS2456 & Geography and Development & $\begin{array}{l}\text { J. Vernon Henderson } \\
\text { Zmarak Shaliz } \\
\text { Anthony J. Venables }\end{array}$ & September 2000 & $\begin{array}{l}\text { R. Yazigi } \\
37176\end{array}$ \\
\hline WPS2457 & $\begin{array}{l}\text { Urban and Regional Dynamics in } \\
\text { Poland }\end{array}$ & $\begin{array}{l}\text { Uwe Deichmann } \\
\text { Vernon Henderson }\end{array}$ & September 2000 & $\begin{array}{l}\text { R. Yazigi } \\
37176\end{array}$ \\
\hline WPS2458 & $\begin{array}{l}\text { Choosing Rural Road Investments } \\
\text { to Help Reduce Poverty }\end{array}$ & Dominique van de Walle & October 2000 & $\begin{array}{l}\text { H. Sladovich } \\
37698\end{array}$ \\
\hline WPS2459 & $\begin{array}{l}\text { Short-Lived Shocks with Long-Lived } \\
\text { Impacts? Household Income } \\
\text { Dynamics in a Transition Economy }\end{array}$ & $\begin{array}{l}\text { Michael Lokshin } \\
\text { Martin Ravallion }\end{array}$ & October 2000 & $\begin{array}{l}\text { P. Sader } \\
33902\end{array}$ \\
\hline WPS2460 & $\begin{array}{l}\text { Labor Redundancy, Retraining, and } \\
\text { Outplacement during Privatization: } \\
\text { The Experience of Brazil's Federal } \\
\text { Railway }\end{array}$ & $\begin{array}{l}\text { Antonio Estache } \\
\text { Jose Antonio Schmitt } \\
\text { de Azevedo } \\
\text { Evelyn Sydenstricker }\end{array}$ & October 2000 & $\begin{array}{l}\text { G. Chenet-Smith } \\
36370\end{array}$ \\
\hline
\end{tabular}

